\title{
Wierzchołek świata. Aline Valangin i dolina Onsernone
}

\section{https://doi.org/10.19195/2084-4107.15.6}

Gęste lasy, malownicze wąwozy i szumiące potoki wartko spływające z gór cechują krajobraz położonej w kantonie Tessyn, na pograniczu szwajcarskowłoskim, doliny Onsernone. Dzięki ustronnemu położeniu zachowała ona swój pierwotny charakter i surowe piękno. To właśnie tutaj w latach trzydziestych i czterdziestych XX wieku pisarka Aline Valangin (właśc. Aline Ducommun, primo voto Rosenbaum, secundo Vogel; 1889-1986) stworzyła w swojej letniej posiadłości w Comologno niezwykłą oazę wolności i pokoju. Ta niepospolita kobieta - z wykształcenia pianistka i psychoanalityczka - gościła w swoim domu tak sławne postaci, jak Kurt Tucholsky, Elias Canetti, Ignazio Silone czy Wladimir Vogel, oraz udzielała schronienia wielu politycznie prześladowanym artystom. Do kręgu jej przyjaciół należało wielu koryfeuszy świata nauki i sztuki, a jej domy w Zurychu i Comologno odgrywały rolę wybitnych salonów literackich i gromadziły przedstawicieli najróżniejszych dziedzin artystycznych. Niniejsze rozważania poświęcone są kwestiom postrzegania, doświadczania i zdobywania tessyńskich gór zarówno w utworach autorstwa Valangin, jak i w dziełach biograficznych o niej, ze szczególnym uwzględnieniem perspektywy narracji - z zewnątrz i od wewnątrz.

Szwajcarska autorka Eveline Hasler podejmuje w powieści biograficznej Aline und die Erfindung der Liebe (2000) próbę (re)konstrukcji obrazu doliny Onsernone jako specyficznej „doliny poetów”, prezentując przy tym subtelną analizę interakcji pomiędzy konserwatywnymi, przywiązanymi do tradycji mieszkańcami a ekstrawaganckimi artystami, którzy odnaleźli w tessyńskich górach azyl oraz źródło inspiracji. Akcja powieści obejmuje przede wszystkim lata spędzone przez Valangin w położonej w Comologno letniej siedzibie zwanej La Barca (pomiędzy rokiem 1929 a końcem wojny); w retrospekcjach przywoływane zostają zaś przełomowe dla pisarki momenty z lat wcześniejszych. Do tych ostatnich zaliczyć należy niewątpliwie skomplikowaną, naznaczoną przemocą psychiczną relację z matką ${ }^{1}$, jak również znajomość z Carlem Gustavem Jungiem $\mathrm{i}$ jego kołem psychoanalitycznym oraz bliskie kontakty z grupą dadaistów w $\mathrm{Zu}$ rychu (Hugo Ball, Hans Arp czy Sophie Taeuber). Wspomnieć warto również o zasługach Valangin jako gospodyni salonu artystycznego w Baumwollhof, zuryskiej siedzibie pisarki i jej pierwszego męża, wybitnego prawnika Wladimira Rosenbauma, gdzie gościli między innymi James Joyce, Joseph Roth i Robert Musil. Owe lata i przeżycia ukształtowały Aline Valangin, która przeistaczała się stopniowo w koneserkę sztuki oraz świadomą swojej wartości nowoczesną

1 P. Kamber, Geschichte zweier Leben. Wladimir Rosenbaum \& Aline Valangin, Zürich 1990, s. $33-52$. 
kobietę żyjącą w „otwartym” małżeństwie i odważnie stawiającą czoła coraz to nowym wyzwaniom, by w połowie lat trzydziestych ostatecznie odkryć w sobie powołanie pisarskie.

W kontekście podejmowanej w niniejszym tekście problematyki podkreślić należy, że Eveline Hasler koncentruje się w swojej powieści biograficznej na perspektywie przybyszów do doliny. Aline Valangin, jako autorka kreśląc w swoich powieściach (Die Bargada, 1943 / Dorf an der Grenze, 1982) i opowiadaniach (Tessiner Erzählungen, 2018) obraz pełnej trosk codzienności mieszkańców Onsernone lat trzydziestych i czterdziestych, preferuje natomiast punkt widzenia miejscowych. W jej opowieściach pojawiają się również odmieńcy, wyrzutki, partyzanci, przemytnicy i wygnańcy - a wszyscy oni znajdują w dolinie bezpieczne schronienie; tessyńskie góry okazują się azylem dla każdego potrzebującego, niezależnie od wyglądu, pochodzenia czy poglądów politycznych.

\section{Dolina i artyści}

Eveline Hasler od samego początku eksponuje w swojej powieści aspekt przestrzeni i wielokrotnie kieruje uwagę czytelnika na samo miejsce akcji, jako że dolina Onsernone zajmuje w świadomości jej mieszkańców szczególne miejsce w przestrzeni geograficznej:

Ojciec pokazał to Luce na mapie: „Wioski w Onsernone są w pewnym sensie wierzchołkiem świata. Wyobraź sobie, Luca, kalenicę, z której woda spływa na północ i południe. Za Sprugą można pójść leśną ścieżką spacerkiem do Włoch, a jeżeli ktoś jest dobrym piechurem, to dostanie się przez Domodossolę na zachód do Francji. Z drugiej strony droga prowadzi przez przełęcz Św. Gottharda do Svizzera interna, stamtąd wzdłuż Renu do Austrii i Niemiec"2.

Przywołana w powyższym cytacie perspektywa jest interesująca i wieloznaczna: z jednej strony, chodzi bowiem o (polityczną) granicę między różnymi krajami, z drugiej zaś - obraz ten przywołuje wizję wolności i (wewnętrznego) spokoju, jak również wielość szans i możliwości, które można dowolnie wykorzystać. Poddająca się spojrzeniu nieograniczona przestrzeń definiowana jest również poprzez aspekt duchowy, który zachęca do refleksji nad własnym miejscem w świecie. Opisana w taki sposób dolina Onsernone staje się miejscem skrzyżowania rzeczywistości i imaginacji, które jawi się czytelnikowi jako miejsce graniczne pomiędzy życiem i sztuką — forma transgresji, która charakteryzuje twórczość Valangin ${ }^{3}$.

${ }^{2}$ E. Hasler, Aline und die Erfindung der Liebe, München 2004, s. 102. Ten i inne przekłady - M.M.K.

${ }^{3}$ O geopoetyce w literaturze por. B. Piatti, Die Geographie der Literatur. Schauplätze, Handlungsräume, Raumphantasien, Göttingen 2008, s. 289. 
Kontakt z tak szczególnym miejscem inspiruje do przedefiniowania własnej tożsamości oraz staje się impulsem do rozwoju osobistego. To bardzo kusząca koncepcja, zwłaszcza dla artystów. W powieści przedstawiona została ona na przykładzie postaci Ignazia Silone, włoskiego pisarza i kochanka Valangin, przy jednoczesnej refleksji na temat problematyki tolerancji i działań na rzecz światowego pokoju.

Aline Valangin stosunkowo wcześnie zetknęła się z inicjatywami ruchu na rzecz pokoju (Friedensbewegung), ponieważ jej dziadek ze strony ojca, Elie Ducommun, laureat Pokojowej Nagrody Nobla w roku 1902, był jednym z najbardziej zaangażowanych orędowników owej idei. Do końca życia pisarka pozostała wierna jego spuściźnie, między innymi poprzez udzielanie aktywnego wsparcia emigrantom jeszcze podczas swojego pobytu w Zurychu. Także w Comologno jej dom stał zawsze otworem dla wszystkich potrzebujących pomocy, a jej przyjaciele i podopieczni z wdzięcznością doceniali jej działalność na tym polu. Udało jej się bowiem stworzyć przestrzeń niezbędną im wszystkim dla rozwijania ich kreatywności i aktywności twórczej — przestrzeń wolną od opresyjnych konwencji oraz umożliwiającą pogłębioną refleksję nad ludzką egzystencją:

Potem powiedział pojednawczo: „Paolo, rozumiem twoją złość, ale od tej kobiety, którą widocznie obaj - na nasze szczęście lub nieszczęście - kochamy, nauczyłem się wiele o życiu, o ludziach i o atmosferze, w której rozkwita prawdziwe człowieczeństwo. Jej tolerancja, Rossi, jest dla mnie przykładem, a Barca, jako arka dla najróżniejszych ludzi czyż nie jest modelem tej federacyjnej Europy, której wizję ma przed oczami twój brat Ernesto?"4.

Mieszkańcy Comologno z początku patrzyli na przyjezdnych ze zdziwieniem i konsternacją. Tym $\mathrm{w}$ większości biednym, zahartowanym ciężką pracą ludziom przybysze z miasta wydawali się postaciami jakby z innego świata: „Palazzo jest ciałem obcym we wsi. Ci za jego murami mają swoje własne prawa"s. Nie unikali jednak kontaktów, chętnie pracowali dla zamiejscowych i traktowali ich często wręcz jako mile widziane źródło dochodów, ponieważ w ich wyobrażeniu wszyscy przybysze byli bogaczami.

Relacje między wsią a artystami nie były wolne od skandali. Erotyczna bezpruderyjność artystów była dla chłopów we wsi czymś niezwykłym i trudnym do zaakceptowania. Nowoczesny model kobiecości, „,nowa istota [...] wolna, błyskotliwa, mądra, dumna, nieobciążona żadnym poczuciem winy"', był sprzeczny z ich tradycją, zwyczajami i wyobrażeniami. Pomimo to Valangin nie została wyklęta ani jednoznacznie osądzona przez społeczność wsi za swoją erotyczną swobodę. Prawdopodobnie pomogła jej pozycja osoby z zewnątrz, której paradoksalnie właśnie dlatego pozwalano na więcej i przyznawano więcej wolności.

\footnotetext{
${ }^{4}$ E. Hasler, op. cit., s. 153-154.

5 Ibidem, s. 100.

${ }^{6}$ Ibidem, s. 166.
} 
Hasler sugeruje w swojej powieści, jakoby mieszkańcy wsi postrzegali artystów przede wszystkim jako Innych, a nie Obcych. To interesujący punkt widzenia: inność nie implikuje mianowicie ani przymusu bezpośredniego zajęcia stanowiska, ani przedstawienia alternatywy; a poza tym nie zawiera w sobie zarzewia konfliktu. To kategoria, która zaspokaja, przynajmniej w pewnym stopniu, ludzką potrzebę bezpieczeństwa. Skonstatować jednak należy, że uciekamy w ten sposób od konieczności odpowiedzi na pytanie o aspekt obcości w inności i unikamy potrzeby określenia własnego stanowiska ${ }^{7}$.

Dla większości przybyszów dolina Onsernone pozostaje tylko przystankiem, prędzej czy później opuszczają Comologno i szukają szczęścia gdzie indziej. Ale dla Aline Valangin pobyt tutaj — w tym również interakcje z mieszkańcami wsi i obcowanie z górami - stał się swego rodzaju sytuacją graniczną, która skierowała jej życie na nowe tory. Właśnie tutaj odnalazła bowiem nową misję życiową i zaczęła tworzyć własne dzieła:

Ale Aline nie należy do tych muz, które dają się zniszczyć geniuszom, których inspirowały. Pobudzała wprawdzie kreatywność w innych, ale przy tym zawsze obstawała przy swojej niezależności i potrafiła zachować czas i siłę do pielęgnowania własnych uzdolnień. Tak jak Silone zaczyna teraz zamieszkiwać słowa, jej nowa miłość to pisanie. Pisze z tą samą chłodną pasją, z którą grała na fortepianie swoje fugi. Nie z dźwięków, a ze słów buduje teraz temat. Opowieści wiejskie, bez wątpienia; ale w kropli wody odbija się świat ${ }^{8}$.

Dolina Onsernone stała się dla Valangin miejscem autobiograficznym ${ }^{9}$, nieodzownym w procesie osobistego rozwoju i kształtowania tożsamości. Jej własne dzieła literackie współtworzą zaś na zasadzie wzajemności krajobraz kulturowy i symboliczny tej przestrzeni.

\section{Dolina i jej pomnik ze stów}

Wznowienie Tessiner Erzählungen (2018) zawiera opowiadania Valangin, które ukazały się w późnych latach trzydziestych ubiegłego wieku w dwóch tomach: Geschichten vom Tal. Neun Geschichten aus dem Onsernone (1937) i Tessiner Novellen. Sechs Geschichten aus dem Onsernone (1939). Przywołanie nazw geograficznych w tytułach obu dzieł sugeruje zamiar upamiętnienia szczególnego kolorytu tessyńskiej doliny dla potomnych i zapewnienia jej miejsca w szwajcarskiej pamięci zbiorowej. Pisarkę interesuje żywotnie związek pomiędzy przestrzenią

7 Zob. B. Chołuj, Inność w powieściach Teodora Fontane, [w:] M. Janion, C. Snochowska-Gonzales, K. Szczuka, Inny, inna, inne. O inności w kulturze, Warszawa 2004, s. 283-288, tu s. 283.

${ }^{8}$ E. Hasler, op. cit., s. 225.

9 O problematyce miejsc autobiograficznych zob. M. Czermińska, Miejsca autobiograficzne. Propozycja w ramach geopoetyki, ,Teksty Drugie” 2011, z. 5, s. 183-200. 
a ludźmi ją zamieszkującymi, zwłaszcza wpływ surowego środowiska górskiego na wykształcenie się specyficznego typu człowieka. Innym frapującym ją problemem jest kwestia tożsamości indywidualnej, społecznej i narodowej mieszkańców.

W swoich utworach Valangin kreśli obraz niełatwego życia w Onsernone. Jego specyfika związana jest z występowaniem nieurodzajnej gleby, która znacznie utrudnia zarówno uprawę zbóż, jak i hodowlę zwierząt. Dlatego mieszkańcy cierpią biedę, która zmusza mężczyzn do poszukiwania pracy sezonowej w miastach leżących poza doliną. Regularna nieobecność mężczyzn powoduje, że kobiety są wyjątkowo samodzielne i pewne siebie. Pod nieobecność mężczyzn w sposób naturalny nabyły prawo do współdecydowania o sobie i losach rodziny i nie dają go sobie odebrać nawet w czasach, kiedy ojciec, mąż, syn czy brat przebywa w domu. Nie dziwi więc fakt, że właśnie te niezwykłe kobiety są bohaterkami wielu opowiadań. W tej wyjątkowej sytuacji dolina i otaczające ją góry należą bowiem w dużej mierze do kobiet, które są zdane głównie na siebie i muszą poradzić sobie z życiem w szczególnie trudnych warunkach. Właśnie tej umiejętności zawdzięczają swą władzę, a kultywowane przez nie, czasem dziwaczne, obyczaje stanowią, jako dowód ich wyjątkowości, źródło ich niewątpliwej dumy:

Tutaj kobiety robią pranie. Robią to w dziwny sposób. Nie piorą rękoma, jak czynią to kobiety na całym świecie, one piorą stopami. Chwytają rożek mokrej tkaniny dużym palcem u stopy i uderzają nim w resztę gładko rozpostartego na kamieniu materiału. Robią to szybko i pewnie, w małych podskokach, ręce oparte na biodrach, plecy pochylone. $\mathrm{Z}$ daleka kobiety wyglądają jak pliszki lub podskakujące wróble. Cała dolina wie, że kobiety z górnej wsi piorą w ten dziwny sposób. Ludzie wyśmiewają się z nich, ale potajemnie je podziwiają, ponieważ nikt nie potrafi im dorównać. To prawdziwa sztuka. A same kobiety w głębi serca są przepełnione pewnością, że z powodu właśnie tej sztuki są więcej warte niż inne kobiety z Doliny, ba może i nawet niż kobiety na całym świecie? Któż to wie? ${ }^{10}$

Oczywiście pomiędzy kobietami z doliny są pracowite i leniwe, mądre i głupie, spokojne i kłótliwe. Nie są one również wolne od typowej dla miejscowych nieufności wobec wszelkich nowinek i zmian. Widać to dobrze na przykładzie projektu Sciory (alter ego autorki) mającego na celu nauczenie mieszkanek wsi zapomnianej sztuki tkactwa, aby mogły dorobić sobie pracą chałupniczą podczas zimowych miesięcy. Bardzo szybko dochodzi do kłótni powodowanych zawiścią i złośliwością, co prowadzi w konsekwencji do klęski całego przedsięwzięcia. W innym opowiadaniu kobiety uczą się sztuki wyplatania ze słomy, aby zgodnie z zarządzeniem władz wyrabiać części do państwowych medali pamiątkowych. Kobiety nie zgadzają się z wyborem liderki grupy, nie chcą jej słuchać i przytaczają na swoje usprawiedliwienie kuriozalne argumenty:

10 A. Valangin, Elektrizität, [w:] eadem, Tessiner Erzählungen, Zürich 2018, s. 128-129. 
I ta Pia. Nie była tutejsza. Jej ojciec przybył z Włoch, jeszcze dobrze tu pamiętano, że przed trzydziestu laty pojawił się tu jako drwal — wtedy był młody i przystojny - i zawrócił w głowie wszystkim dziewczętom. Luisa wyszła wtedy za niego. I chociaż nie żył wcale inaczej niż inni mężczyźni w Dolinie, pozostał w oczach wszystkich czymś osobliwym. Czy przyczyną było to nie do końca zapomniane powodzenie u kobiet, czy trochę wyraźniejsza wymowa, gorliwość w oszczędzaniu, czy też może ostentacyjny sposób, w jaki trzymał się z daleka od wszystkich waśni we wsi: nie zżył się ze wsią, pozostał obcy i nawet do jego dzieci, które przecież tu się urodziły i dorastały, przylgnęła łatka osobliwości ${ }^{11}$.

Tak naprawdę chodzi tu jednak o osobiste animozje, stare i nowe waśnie rodzinne, przynależność partyjną, a nie kwestię obcości, która traktowana jest przez wszystkich instrumentalnie jako dobry pretekst podczas wymiany argumentów na niewygodne tematy.

Pomiędzy kobietami brakuje głębszej więzi czy solidarności. Mieszkanki wsi są kapryśne, kłótliwe, zarozumiałe czy po prostu głupie. Życie w dolinie to nie idylla i niektóre z kobiet muszą zupełnie niewinnie zmierzyć się z uprzedzeniami i przesądami, rozpowszechnianymi często właśnie przez inne kobiety:

To była Claretta, jej chrześnica, córka owej samotnej kobiety, która mieszkała ze swoim dzieckiem w rozwalającym się domu na końcu jaru i o której opowiadano, że jest czarownicą. Dlaczego była czarownicą i co zarzucano jej jako czarownicy, nie było wiadomo. Po prostu była czarownicą i tego nie dało się zmienić. Nikt nie chciał się z nią zadawać, może tylko mężczyźni, a $\mathrm{i}$ to tylko potajemnie... przebywanie w pobliżu jej domu w późnych godzinach przynosiło ujmę... ${ }^{12}$

Córka osławionej czarownicy jest wyszydzana i krzywdzona w szkole, nie może też liczyć na wsparcie dorosłych. Ona sama i jej matka są świadomie separowane od społeczności wsi, żyją na marginesie społeczeństwa i spędzają większość czasu w swojej zagrodzie w górach ${ }^{13}$.

Szczególną pozycję we wspólnocie wsi zajmują jej upośledzeni członkowie jako Inni. Pozostają oni co prawda częścią społeczności gminnej, ponieważ umieszczenie członka rodziny w zakładzie opiekuńczym lub w szpitalu psychiatrycznym uchodzi, z jednej strony, za niegodne, a z drugiej zaś - wymaga ponoszenia kosztów pobytu, ale sytuacja tych osób jest trudna i delikatna. Wsiowy głupek Carlo jest wprawdzie tolerowany jako potomek zasiedziałej w dolinie rodziny, której członkowie popadli w alkoholizm, ale stale jest stygmatyzowany jako Inny. Na swoje utrzymanie zarabia jako chłopak na posyłki. Jednak jego nieobliczalne zachowanie, często pozbawione sensu wypowiedzi, jak również

11 A. Valangin, Das Kreuz, [w:] eadem, Tessiner Erzählungen ..., s. 225-226.

12 A. Valangin, Versöhnung, [w:] eadem, Tessiner Erzählungen..., s. 300-301.

13 Dzieje tej rodziny są tematem powieści Die Bargada i Dorf an der Grenze. 
przypisywany mu dar przepowiadania pogody wzbudzają nieufność mieszkańców wsi, co prowadzi w konsekwencji do wykluczenia go i traktowania jako reprezentanta jakiegoś innego, niezrozumiałego i chaotycznego świata ${ }^{14}$. Nawet pozbawionej uprzedzeń i bywałej w świecie Sciorze wydaje się on zagadkowym medium pomiędzy światami — natury i kultury lub rzeczywistości i snu (a także koszmaru sennego):

Ta twarz! Cóż to była w ogóle za twarz! To był raczej pejzaż z wierzchołkami i pasmami gór, dzikimi zboczami, wąwozami i przepaściami, spustoszonymi lasami, blokami skalnymi, wirami w rozpadlinach, polami po trzęsieniu ziemi, miejscami zejścia lawin i osuwiskami ziemnymi. Z pierwotnego świata tej twarzy spoglądały oczy, jedno małe i przymglone, prawie zakryte przez zaognioną powiekę. Ale z drugiego świecił promień rozsądku zesłany przez Boga z nieba na pustynię świata ${ }^{15}$.

Carlo odznacza się wyjątkową wrażliwością muzyczną i mniej lub bardziej świadomie potrafi odtwarzać pewne dźwięki. Tylko w swojej muzyce, doświadczanej jako unio mystica, odnajduje ucieczkę od świata pełnego niezrozumienia i niepewności. Jednak tak naprawdę słucha go tylko obca Sciora, uważna obserwatorka, która próbuje go zrozumieć oraz docenić jego wyjątkowość. I chociaż brak mu wielu zwykłych cech ludzkich, to jego deficyty zapewniają mu wyjątkową pozycję, ponieważ poprzez swoją niezwykłość staje się on częścią sfery sacrum $^{16}$. Zauważyć i pojąć to może jednak tylko osoba spoza doliny, utalentowana muzycznie artystka i w tym sensie jego pokrewna dusza.

\section{Dolina i wojna}

W powieści Dorf an der Grenze, która ze względu na zawartą w niej krytykę szwajcarskiej polityki emigracyjnej podczas drugiej wojny światowej ukazać się mogła dopiero w roku 1982, Aline Valangin opisuje przeżycia i doświadczenia wojenne mieszkańców Onsernone.

Do tej pory życie w dolinie toczyło się od dziesięcioleci tym samym trybem, który wyznaczały pory roku oraz spowodowana pracą sezonową i wymogami rynku pracy nieobecność mężczyzn we wsi. Nic się nie zmieniało i wszyscy przyjmowali ten stan jako coś zupełnie zwyczajnego: „Wieś nie liczy godzin. Zegar kościelny stanął przed laty. Wskazówki są połamane. Wieniec cyfr okala bezużytecznie pustą tarczę. Czas stoi tu w miejscu"17. Mieszkańcy wsi postrzegają wojnę na początku jako nieznany im żywioł, zjawisko przyrody, które ich samych nie dotyczy. Jednak z biegiem czasu wojna przemienia ich rodzime góry

\footnotetext{
14 Por. K. Moszyński, Kultura ludowa Stowian, t. 2/1. Kultura duchowa, Warszawa 1967, s. 97.

15 A. Valangin, Carlo, der Narr, [w:] eadem, Tessiner Erzählungen ..., s. 95.

${ }^{16}$ K. Moszyński, op. cit., s. 413.

17 A. Valangin, Die Bargada / Dorf an der Grenze. Eine Chronik, Zürich 2002, s. 171.
} 
w miejsce brutalnej walki i konfrontacji z nieznanym i szokującym. Zmiany, które początkowo dotykają dolinę, nie są wyłącznie złe: co prawda mężczyźni zostają powołani do wojska, ale państwo zapewnia wsparcie finansowe. Jednakże niedługo potem rząd domaga się większych dostaw środków spożywczych, czemu trudno sprostać ze względu na nieurodzajną glebę.

Najbardziej spektakularna zmiana dotyczy przebiegającej niedaleko wsi granicy. To do tej pory raczej zapomniane miejsce $\mathrm{w}$ górach zyskuje znienacka na znaczeniu i zostaje obsadzone silnymi oddziałami włoskich i szwajcarskich pograniczników. Nagle i niespodziewanie mieszkańcy wsi stają twarzą w twarz z uciekinierami, którzy nielegalnie przekraczają granicę. Wbrew zwyczajowej nieufności wobec obcych wieś serdecznie przyjmuje uchodźców, zwłaszcza kobiety i dzieci budzą natychmiast powszechne współczucie. Ludzie pragną szczerze udzielić im schronienia i dlatego reagują z niezrozumieniem i oburzeniem na państwowe rozporządzenie, które nakazuje odsyłanie uciekinierów z powrotem za granicę. Czują bowiem litość w stosunku do ludzi, którzy musieli opuścić swoje strony rodzinne i pozostawić tam cały swój dobytek, tym bardziej że uzmysławiają im oni kruchość ich własnej egzystencji w konfrontacji z nieubłaganym losem: ,Jakież to dziwne: więc nie wystarczyło poświęcić majątku i ostatkiem sił uciec jako żebrak za granicę? Żądano jeszcze więcej. Czegóż jeszcze?" ${ }^{18}$. Mieszkańców wsi irytują też przemytnicy ludzi, którzy bez skrupułów żądają od Żydów bajońskich sum za przeprowadzenie ich przez granicę. $Z$ biegiem czasu sytuacja zaostrza się i fala uchodźców upodabnia się do nieopanowanego żywiołu:

Dwie żydowskie rodziny zapoczątkowały wszystko. Były zwiastunami strumienia ludzi, który spływał teraz z gór. Pojawiali się pojedynczo lub w grupach, objuczeni dużym bagażem lub w porwanych łachmanach, na wpół zamarznięci i zagłodzeni, poważnie ranni, niezdolni do wyjaśnień, obłąkani. Wzmocniona straż na granicy nie radziła sobie wcale. „Ludzie spadają z gór jak wodospady, kiedy pada deszcz", skarżył się Bozi, „Przepływają człowiekowi pomiędzy palcami”"19.

Z biegiem czasu granicę przekraczają już nie tylko Żydzi, ale i uciekinierzy z całego świata. Mieszkańcy wsi solidaryzują się bez wyjątku z nimi wszystkimi i podważają rację dekretów państwowych, które w nieprzewidywalny sposób decydują o przyjęciu lub deportacji azylantów.

Również inne grupy ludzi poza uchodźcami anektują w międzyczasie otaczające wieś góry. Kiedy po pewnym czasie kończą się zapasy, pojawiają się przemytnicy, którzy zaopatrują mieszkańców wsi w żywność i artykuły luksusowe. Narażają się przy tym na duże ryzyko, ponieważ muszą przedzierać się przez niegościnne i niebezpieczne tereny. Znają oni jednak dobrze okolicę, więc góry stają się właściwie ich sojusznikiem — choć są źródłem wielu zagrożeń, zapewniają jednocześnie ochronę i bezpieczeństwo:

18 Ibidem, s. 207.

19 Ibidem. 
Pastwiska rozciągały się szeroko i łagodnie o kilka godzin drogi wokół chaty. Wiele śladów prowadziło do wąskiej dolinki, w której pomiędzy grzbietami gór leżało małe jezioro, a raczej stawek, o przejrzystej zimnej wodzie, którą ciemne dno czyniło czarną. Parę modrzewi, które tam się jeszcze ostało, nosiło ślady uderzenia pioruna. Na tej wysokości rosły jeszcze krzaczki jagód i różaneczniki alpejskie. Powyżej wszystko było łyse i puste. Tylko nieliczne ptaki zataczały tu swoje kręgi. A poza tym nic żywego. Krótka trawa szybko spalona słońcem zieleniła się dopiero późną wiosną. Trochę wyżej na wysokości przełęczy przebiegała granica. Stamtąd rozciągał się daleki widok aż do majaczących w oddali turni, które strome i nieprzychylne mieszkańcom nie miały żadnych nazw. W tej dzikiej, jałowej, kamienistej okolicy pełnej gołoborzy i podstępnych urwisk przemytnicy szukali swojej drogi. Była niebezpieczna i pełna pułapek, ale nie czaił się tu już żaden pogranicznik, żaden żołnierz, żaden pies myśliwski. Szli więc bezpiecznie ${ }^{20}$.

Nastawienie mieszkańców wsi do band przemytników jest niejednoznaczne. Uczciwi ludzie oburzają się na łamiących prawo bandytów, ale inni są zadowoleni, że mogą nabyć pożądane dobra. Przemyt kwitnie przy cichej zgodzie wsi, ponieważ również ci niezadowoleni dochowują tajemnicy. Nikt nie donosi na przemytników, nawet kiedy ci z czasem nieprzyzwoicie windują ceny żywności i nastawiają się głównie na przynoszące największy zysk artykuły luksusowe.

Pomiędzy przemytnikami krążą potajemnie politycznie zaangażowani szpiedzy, którzy chcą poznać jak najwięcej górskich ścieżek, aby wyznaczyć trasy dla oddziałów ruchu oporu. Również ci ludzie szukają w górach bezpiecznego schronienia i obejmują je w swe posiadanie. W górskim odosobnieniu zakładają swoje obozy szkoleniowe i przygotowują się do zamachów:

Partyzanci, o których już prawie zapomniano we wsi, zbierali się w grupy, pod własnymi przywódcami. Byli wyposażeni w broń i wyszkoleni, a napędzała ich wola uwolnienia swojego kraju od plagi ciemiężycieli. Atakowali wroga ze swoich kryjówek w górach, wdawali się w potyczki, wysadzali w powietrze mosty, aby odciąć wroga od wsparcia. Udawało to im się tak dobrze, że zdobywali jedną wieś za drugą, a Niemcy zostali zapędzeni w ostatni zakątek górskiej okolicy. To tylko kwestia czasu, kiedy będą musieli się poddać21.

Jako że poglądy polityczne mieszkańców wsi są zróżnicowane, partyzanci nie otrzymują początkowo nieograniczonego wsparcia, są raczej jedynie tolerowani, ale też nikt nie donosi na nich do władz. W końcu jednak dochodzi na granicy do krwawej bitwy, w której biorą udział nie tylko faszyści, pogranicznicy, partyzanci i uchodźcy, ale i sami mieszkańcy wioski. Niektórzy z nich giną na polu walki.

\footnotetext{
20 Ibidem, s. 220.

21 Ibidem, s. 264.
} 
Wstrząs wywołany tym traumatycznym wydarzeniem powoduje konsolidację całej wspólnoty i budzi przeświadczenie, że w imię słusznej sprawy należy przeciwstawić się aktywnie niesprawiedliwym urzędowym rozporządzeniom. Solidarność powinna przezwyciężyć wszelkie granice, ponieważ „ludzi, którzy walczą o wolność, w ogóle nie ceni się w owych organach, od których coś zależy"22. Dlatego nie wolno unikać obowiązku walki o swoje przekonania i o wspólną sprawę: „Dopiero teraz pojmujemy, że nie możemy stać jak nasz zegar kościelny bez wskazówek. [...] Musimy się zaangażować... musimy otworzyć się na wyzwania czasu i włączyć w walkę o wolność... która jest także naszą wolnością"23.

\section{Podsumowanie}

Na podstawie analizy omawianych dzieł stwierdzić można, że dolina Onsernone lat trzydziestych i czterdziestych XX wieku jawi się jako zaskakująco otwarte miejsce, które staje się schronieniem dla ludzi o różnorakim tle etnicznym i politycznym. Dolina nie jest co prawda wolna od (skrywanych) napięć, ale w gruncie rzeczy przyjmuje wszystkich serdecznie i staje się katalizatorem w kształtowaniu tożsamości, w czasie wojny jest zaś miejscem próby człowieczeństwa w obliczu zagrożenia.

Powieść Eveline Hasler jest przykładem polifonicznej powieści biograficznej, w której partie narratora wszechwiedzącego przeplatają się na przykład z fragmentami pamiętników. Czasem też głos odautorski zostaje całkowicie wyeliminowany na rzecz dialogów bohaterów, bezpośrednich świadków wydarzeń $^{24}$. Jak już wcześniej wspomniano, przestrzeń jawi się w koncepcji autorki jako niezmiernie ważny, a nawet niezbędny nośnik znaczeń i pamięci zbiorowej. W tym kontekście warto zadać pytanie o wpływ nowoczesnych teorii na sposób prezentacji poruszanych problemów. Chodzi tu na przykład o preferowanie kategorii Inności wobec kategorii Obcości w opisie postrzegania artystów przez mieszkańców doliny. Sama Valangin nie podejmuje w swoich tekstach tej kwestii, ponieważ koncentruje się przede wszystkim na analizie interakcji wewnątrz społeczności wsi (chociaż w opowiadaniach pojawia się alter ego autorki, Sciora, to przyjmuje ona raczej rolę niezaangażowanej obserwatorki) i obnaża przy tym nie zawsze chwalebne motywacje postępowania bohaterów.

Interpretacja tekstu Hasler w duchu geopoetyki otwiera niewątpliwie nowe perspektywy, ponieważ pozwala przedyskutować znaczenie związku pomiędzy podmiotem a przestrzenią geograficzną w kontekście kreacji artystycznej

22 Ibidem, s. 332.

23 Ibidem, s. 333.

24 Zob. A. Nünning, Von der fiktionalen Biographie zur biographischen Metafiktion. Prolegomena zu einer Theorie, Typologie und Funktionsgeschichte eines hybriden Genres, [w:] Fakten und Fiktionen. Strategien fiktionalbiographischer Dichterdarstellungen in Roman, Drama und Film seit 1970, red. Ch. von Zimmermann, Tübingen 2000, s. 15-36, tu: s. 28. 
(auto)biografii Aline Valangin. Powieść zaczyna się opisem Palazzo La Barca w Comologno i tworzy w ten sposób kluczową ramę dla opowieści o życiu pisarki. Przestrzeń geograficzna nie stanowi tylko zwykłego tła, lecz raczej przestrzeń różnorodnych doświadczeń ${ }^{25}$, które, z jednej strony, wpłynęły na życie i rozwój intelektualny Valangin, a z drugiej - upamiętniają i współtworzą regionalną i kulturową odrębność doliny Onsernone.

Powieść Valangin Dorf an der Grenze jest nie tylko opowieścią o wojnie, ale także o doświadczeniu granicy, które niespodziewanie okazuje się także wyzwaniem i szczególnym rodzajem doświadczenia siebie w obliczu wydarzeń, które burzą dotychczasową egzystencję. Zmusza bowiem do refleksji nad sensem i znaczeniem granicy kraju czy państwa, a więc nad problemem, który do czasu wojny w ogóle nie istniał w świadomości mieszkańców wsi. Pobliska granica była dla nich czymś znanym i zwyczajnym, co nie powodowało żadnych konsekwencji. Teraz jednak staje się ona miejscem próby ich człowieczeństwa; w obliczu konfrontacji z przemocą, cierpieniem i śmiercią rodzi się jakoby „,cielesna świadomość granicy" ${ }^{26}$. Aline Valangin partycypuje więc w dyskusji o istocie szwajcarskiego patriotyzmu nie tylko poprzez swoją zdecydowaną krytykę szwajcarskiej polityki emigracyjnej w czasie drugiej wojny światowej, ale również poprzez refleksję nad metaforycznym pojęciem granicy jako miejsca doświadczenia różnorakich — między innymi inspirujących lub traumatycznych — sytuacji granicznych.

Z języka niemieckiego przetożyła Monika Mańczyk-Krygiel

${ }^{25}$ E. Rybicka, Geopoetyka. Przestrzeń i miejsce we współczesnych teoriach i praktykach literackich, Kraków 2014, s. 280.

${ }^{26}$ P. von Matt, Der Traum an der Grenze. Zur literarischen Phantasie in der Schweiz, [w:] idem, Die tintenblauen Eidgenossen. Über die literarische und politische Schweiz, München 2004, s. 113122 , tu s. 115 . 